\title{
Financial Literacy and Consumer Debt: A Survey of Low-Income Households in Depok, West Java, Indonesia
}

\author{
Angelica Fadya Noventi ${ }^{1}$, Dwi Nastiti Danarsari ${ }^{1 *}$ \\ ${ }^{1}$ Faculty of Economics and Business, Universitas Indonesia \\ Email: dwi.nastiti@ui.ac.id
}

\begin{abstract}
This study aims to examine the impact of financial literacy on consumer debt as measured by debt-to-income ratio, number of lenders, and net worth among low-income households in overindebted condition. The key components of financial literacy used are numeracy and money management skills. This study is conducted through a survey on 103 low-income households in Depok, West Java. The main finding from the analysis is that neither numeracy nor money management skills significantly affect debt-to-income ratio and net worth. However, money management skills are found to have a significant influence on the number of lenders. As money management skills improve, the number of lenders increases. Numeracy skills, however, has no significant effect on the number of lenders. This finding differs from that of previous studies, which suggest that money management skills would decrease the number of lenders. This study has an implication on educational programs intended to enhance financial literacy among lowincome households.
\end{abstract}

Type of Paper: Empirical

Keywords: Financial literacy, Debt, Money management, Numeracy Skills, Low-Income, Indonesia

\section{Introduction}

Financial literacy means an understanding of financial matters. According to Potrich et al. (2016), financial literacy is the mastery of a set of knowledge, attitudes, and behaviors that have assumed a fundamental role in allowing and enabling people to make responsible decisions as they strive to attain financial wellbeing. This statement emphasizes that financial literacy is important in making a proper financial decision. Rivlin (1999) suggested that financial literacy can support economic functions. He argued that the more society knows about the benefits of financial products and services, the more financial transactions people will make and this in turn will stimulate the economy. Mukalenge (2013) supported this argument by stating that financial literacy is one of the key functions of economic growth in a country.

Indonesia's financial literacy level is $32 \%$. This number is relatively low compared to Singapore, with a financial literacy of 59\% (Standard and Poor's, 2014). Singapore has positioned itself as the country with the highest literacy in Southeast Asia, followed by Myanmar and Malaysia 
with financial literacy levels of $52 \%$ and $36 \%$, respectively. Despite the low number, Indonesia's financial literacy rate has actually increased in just one year. The Financial Services Authority (Otoritas Jasa Keuangan or OJK) confirmed that Indonesians' financial literacy in 2013 was just $21.8 \%$.

As an emerging country, Indonesia's economy is mostly driven by households consumption. According to the Central Bureau of Statistics of the Republic of Indonesia (Badan Pusat Statistik or BPS, 2016), household consumption is the biggest contributor to Indonesia's economic growth. As household consumption grows, the demand for credit also grows. This household consumption demand is mainly made up of credit demand for property, automotive vehicles, and 'other' daily household consumption. The biggest contributor, however, are loans under the 'other' category, which covers loans for grocesies, furniture, electronic appliances, and other related household needs. Aside from loans provided by formal institutions registered with Bank Indonesia, Indonesians may also obtain loans from family and friends. According to the Indonesian Access to Finance Association (Perkumpulan Akses Keuangan Indonesia or PAKINDO, 2016) $41.5 \%$ of Indonesians have borrowed from family or friends to meet their credit needs. Family and friends are considered as analternative option to obtain debts in an easier way.

The rapid growth in debt implies that Indonesians are very likely to acquire loans. This situation leads to a potential debate on whether Indonesians are capable of controlling their debts. A previous study found that that poor financial literacy leads to poor financial decisions (Lusardi and Tufano, 2009). This is because financial literacy is found to be linked to the ability to budget, save money, and control spending (Perry and Morris, 2005). By this mechanism, some studies have found that financial literacy is positively correlated with debt problems. Disney and Gathergood (2013) found that borrowers with poor financial literacy hold higher shares of high-cost credit than those with higher literacy. It was also found that individuals with poor financial literacy are more likely to lack confidence in interpreting credit terms and to exhibit confusion over financial concepts. They are also less likely to engage in behavior that might help them to improve their awareness of the credit market. Thus, in summary, poor financial literacy is correlated with higher debt burdens, incurring greater fees, loan defaults, and loan delinquency.

Since low financial literacy is expected to occur among people in the low-income segment, it would be interesting to investigate whether their incapability in understanding financial concept may lead to their over-indebted condition. Low-income individuals are found to have worse financial management than medium- to high-income individuals. As a comparison, Kadence International found that 3 out of 4 Indonesian always save their money based on a survey of Share of Wallet in 2013. This survey was conducted on respondents with permanent jobs, high educationals background, and monthly incomes above the regional minimum wage. Only 1 out of 4 are "broke," which refers to individuals who spend more than they earn. However, Perkumpulan Akses Keuangan Indonesia (PAKINDO, 2016) found that micro-clients tend to take multiple loans and barely make any savings. Moreover, it is interesting to find that 9 out the 20 default micro clients had only one or two loans but they still defaulted. This situation can happen under the assumption of low educational background among low-income households, which leads to poor financial literacy as suggested by Standard and Poor's (2014). BPS (2015) found that $45.19 \%$ of laborers have only finished elementary school and $17.77 \%$ are junior high school graduates. 
The easier access to debt nowadays and the findings on how low income leads to low financial literacy have motivated the authors to conduct research on this topic. This study aims to investigate whether financial literacy among low-income households affects the number of lenders they have. The chosen method is a survey conducted through interviews with the target respondents in Depok.

Depok today has 1,803,708 citizens and 41,021 of them are low-income citizens who qualify for the Social Security Card (Kartu Perlindungan Sosial or KPS) according to the Municipal Government of Depok (2016). Due to the easy access and availability of the data, the authors chose Depok as the location for sample observation. In addition, due to Depok's place as a part of Greater Jakarta, it receives similar influences upon its financial developments as the national capital (DKI Jakarta). Therefore, the citizens in Depok can be expected to be aware of the financial products and services commonly found these days. Although West Java has the third highest rate of absolute poverty in Indonesia (BPS, 2017), Depok has the lowest rate of poverty in West Java, which provides us with the right target respondents for this study.

The paper is structured as follows. Section 2 provides an overview of the literature on poverty in Indonesia, the definition and measurement of financial literacy, aand the role of financial literacy in influencing financial behavior. Section 3 describes the research design, methodology, and sampling method in processing the collected data. Section 4 presents the results of the discussion about the relationship of numeracy and money management skills to the debt-toincome ratio, number of lenders, and net worth. In section 5 the conclusion is elaborated with the addition of policy implications.

\section{Literature Review}

According to data from the World Bank (2015), there are 2.927 million people with low to middle income in Indonesia. Their income have increased significantly in the past ten years. As of 2015, the total income produced by this particular segment has reached 5.86 trillion US Dollars. According to Badan Pusat Statistik (BPS-Statistics Indonesia 2016), Indonesia's economic growth is mostly driven by households consumption. Therefore, as incomes increase, the consumption among low-income households in Indonesia also increases. The growth in household consumption understandably leads to a growth in the demand for credit. This demand on credit for household consumption mainly consists of demand for property, automotive vehicles, and other items of daily household consumption. The biggest contributor, however, are loans under the "others" category, which covers demands for groceries, furniture, electronic appliances, and other related household needs.

Low-income households in Indonesia prefer to utilize informal sources of loans. They prefer to get loans from moneylenders (86\%), friends/relatives (31\%), and Arisan/ROSCA $(23 \%)$ (PAKINDO, 2016). These loans are fast and require little or no documentation, which makes them easy to get. Arsyianti \& Beik (2015) also suggest that low-income households in Indonesia are more likely to have higher debt-to-income ratio than those with a higher income. They also argue that low-income households in Indonesia represent 20 percent of the population above the poverty line in Indonesia. They are not categorized as poor, whether by the World Bank or by the Indonesian Bureau of Statistics, but they are still struggling to reach reasonable living standards (Arsyiati \& Beik, 2015). 
There are various definitions of financial literacy according to prior studies and literature. A widely accepted definition is the one by OECD INFE (2011), which characterizes financial literacy as a combination of awareness, knowledge, skills, attitude, and behavior necessary to make sound financial decisions and ultimately achieve individual financial well-being. Financial literacy has a core meaning about financial knowledge or understanding and how one can apply that knowledge in making financial decisions.

Despite the variety of components used to measure financial literacy, definitions of financial literacy consistently emphasize financial knowledge, so many authors have used financial knowledge as a component in evaluating and measuring financial literacy. In order to fit the sample of low-income households, French and McKillop (2016) used numeracy skills and money management skills as variables to measure financial literacy. Numeracy is the ability to reason and to apply simple numerical concepts (Brooks and Pui, 2010). One can be considered to have at least basic numerical knowledge if one can understand simple mathematical equations. Money management is the practical realization of the person's or family's financial capabilities, which includes a process that covers planning, search for information, decision-making, implementation, and control (Raijas, 2011). Unlike numeracy skills, money management skills are not measured through the respondents' ability to calculate. Excellent or poor management skills are judged according to the respondents' ability to manage their money (whether they can construct a spending budget), good monitoring practices, and discipline in paying bills and sticking to their expenditure plan. An assessment for this variable can be made by giving out statements that allow the respondents to express the most relatable behavior to them by choosing a number or on the scale provided in the questions.

\section{Research Methodology}

\subsection{Research Design}

The research design that will be used for this study is a conclusive-descriptive research with quantitative analysis. The researcher will collect the information from one sample of respondents only once. Thus, the single cross-sectional design is used. The data collection method is a survey through interviews with the respondents in Depok. The interview is supported by a questionnaire that consists of 5 sections such as screening questions, respondent profile, financial capacity, financial activities, and financial understanding. Only one participant per household is interviewed. The respondents who qualify for the research are individuals who have debts within the last 3 months and this indebtedness must have lasted for more than 9 months. The data gathered from the sample will be processed with the software SPSS 22 through a statistical method of regression.

\subsection{Sampling Method}

This research uses a non-probability judgmental sampling. During the collection of the data, snowball sampling is also used by the interviewers since many respondents can refer to other target respondents. Due to the regression analysis used in this study, there are several rules to be followed. The general rule of thumb for a correlation or regression in determining the sample size is no less than 50 participants with the number increasing with larger numbers of independent variables (IVs) (Voorhis and Morgan, 2007). There are other two general rules of thumb that can be used. Harris (1995) suggested that if there are five or fewer predictors, the number of participants should exceed the number of predictors by at least 50 . This means the 
total number of participants equals the number of predictor variables plus 50. Meanwhile, if there are six or more predictors, an absolute minimum of 10 participants per predictor variable is more appropriate. 103 respondents have been collected to match the target sample numbers.

\subsection{Research Model}

This research will apply the same research model used by French and McKillop (2016). In order to represent the condition of over-indebtedness, the dependent variables (DV) used in this study are the debt-to-income ratio (DTIR), the number of lenders (NOL), and net worth (NW). This research also uses the respondents' socio-economic situation as control variables in the regression analysis. The control variables used are gender (gend), age (age), marital status (ms), household size (hs), house owner (ho), income (inc), and education (edu). With these control variables, the regression models that can be constructed are presented below.

$$
\begin{aligned}
& \mathrm{DTIR}=\alpha+\beta \mathrm{NS}+\beta \mathrm{MMS}+\beta \text { gend }+\beta \text { age }+\beta \mathrm{ms}+\beta \mathrm{hs}+\beta \mathrm{ho}+\beta \text { inc }+\beta \text { edu } \\
& \mathrm{NOL}=\alpha+\beta \mathrm{NS}+\beta \mathrm{MMS}+\beta \text { gend }+\beta \text { age }+\beta \mathrm{ms}+\beta \mathrm{hs}+\beta \mathrm{ho}+\beta \text { inc }+\beta \text { edu } \\
& \mathrm{NW}=\alpha+\beta \mathrm{NS}+\beta \mathrm{MMS}+\beta \text { gend }+\beta \text { age }+\beta \mathrm{ms}+\beta \mathrm{hs}+\beta \mathrm{ho}+\beta \text { inc }+\beta \text { edu }
\end{aligned}
$$

\section{Results and Discussion}

\subsection{Descriptive Results}

Table 1 shows descriptive statistics of the respondents' profile. This study has successfully collected 103 participants consisting of 42 male and 61 female respondents. The majority of participants are in the age category of 35 to 49 years with a percentage of $52 \%$. The smallest age category of participants is 18 to 24 years old at only $8 \%$. This is perhaps because respondents in the latter age category do not engage in many debt-related activities or have permanent jobs. Most participants are married and live together with their partners $(84 \%)$ with an average household size of 4 individuals. The participants who own a house account for $37 \%$ while the rest rent their place of living. Singleincome households have the highest share in the sample (74.8\%). Meanwhile, households with multiple incomes account for only $25.2 \%$. This situation is common in Indonesia where families only depend on the males' capabilities to generate income as the head of the household while females' roles and responsibilities are mostly those of a stay-at-home housewife.

The results shown in Table 2 indicate that the average weekly income of the low-income households in Depok is Rp 785.169,90 and their weekly expenditure differs very little from the income at $\mathrm{Rp} 781.173,14$. With an average household size of 4 individuals, this gives a household income per capita of Rp 198.216,91 per week. The average amount of total debt, however, is Rp 13.452.747,57. The very small difference between average weekly income and average weekly expenditure indicates that low-income households in Depok struggle to maintain their financial situation. Despite this constraint, the respondents still have debts that are significantly larger than their average weekly income.

\subsection{Regression Analysis}

The participants' financial literacy level is measured by assessing their answers on numerical 
Table 1. Demographic description of the sample

\begin{tabular}{|c|c|c|}
\hline \multicolumn{2}{|c|}{ Variable } & Mean \\
\hline Gender & Female & 0.59 \\
\hline & Male & 0.41 \\
\hline Age & $18-24$ & 0.08 \\
\hline & $25-34$ & 0.31 \\
\hline & $35-49$ & 0.52 \\
\hline Marital Status & over 50 & 0.09 \\
\hline & Married and live together & 0.84 \\
\hline Income status & Single & 0.16 \\
\hline & Single Income & 0.75 \\
\hline House Ownership & Double Income & 0.25 \\
\hline Household Size & House owner & 0.37 \\
\hline $\mathbf{N}$ & House rent & 0.63 \\
\hline & & 3.9 \\
\hline
\end{tabular}

Source: Survey Data

Table 2. Household Income \& Assets and Household Expenditure \& Total Debt (In Rupiah)

\begin{tabular}{|l|c|c|c|c|}
\hline & Average & Min & Max & Std.D \\
\hline Income and assets & $785,169.90$ & 50,000 & $1,162,500$ & $191,738.45$ \\
\hline $\begin{array}{l}\text { Weekly household } \\
\text { income }\end{array}$ & $198,216.91$ & 12,500 & 500,000 & $86,109.71$ \\
\hline $\begin{array}{l}\text { Weekly household } \\
\text { income per capita }\end{array}$ & & & $3,925,000$ & $538,799.38$ \\
\hline Expenditure and total debt & 17,500 & & $30,219,029.53$ \\
\hline $\begin{array}{l}\text { Weekly household } \\
\text { expenditure }\end{array}$ & $781,173.14$ & 85,000 & $270,000,000$ & \\
\hline Total household debt & $13,452,747.57$ & &
\end{tabular}

Table 3. Summary statistics for responses to numeracy questions

\begin{tabular}{|l|c|c|c|c|c|c|c|c|}
\hline \multirow{2}{*}{} & \multicolumn{2}{|c|}{ Simple Interest } & \multicolumn{2}{c|}{ Division } & \multicolumn{2}{c|}{ Percent } & \multicolumn{2}{c|}{ Compound Interest } \\
\cline { 2 - 9 } & Frequency & Percent & Frequency & Percent & Frequency & Percent & Frequency & Percent \\
\hline Correct & 56 & 54.4 & 78 & 76 & 66 & 64 & 2 & 2 \\
\hline Incorrect & 47 & 45.6 & 25 & 24 & 37 & 36 & 101 & 98 \\
\hline Total & 103 & 100 & 103 & 100 & 103 & 100 & 103 & 100 \\
\hline
\end{tabular}

Source: Survey Data

skill questions. There are four questions provided in the questionnaire, divided into four categories. The first question is about simple interest, the second question is a division problem, the third question asked is about percentages, and the last question is about compound interest. In the first question, participants were asked 'If Bambang owes Rp 2.000.000 to the bank and the interest rate charged is $15 \%$ per year, how much money would he owe to the bank after one year?' The division question was 'If there are 5 people who have the winning numbers and the prize is Rp 20.000.000, how much will each of them get?' The percentage question was 'If the chance of catching a disease is 10 percent, how many people out of 1000 would be expected to catch the disease?' The Compound Interest question was 'Let's say you have Rp 2.000.000 in your bank account and the account earns $10 \%$ interest per year. How much would you have in the account at the end of two years?' 
Table 4. Distribution of questions answered correctly

\begin{tabular}{|c|c|c|}
\hline Total Number of Questions Answered Correctly & Frequency & Percentage \\
\hline 0 & 11 & 10.7 \\
\hline 1 & 17 & 16.5 \\
\hline 2 & 41 & 39.8 \\
\hline 3 & 32 & 31.1 \\
\hline 4 & 2 & 1.9 \\
\hline Total & 103 & 100.0 \\
\hline
\end{tabular}

Source: Survey Data

Table 5. Money management skills: 'indicate the extent to which you agree with each of the following statements ..."

\begin{tabular}{|c|c|c|c|c|c|}
\hline & $\begin{array}{l}\text { (1) \& (2) } \\
\text { Strongly } \\
\text { disagree / } \\
\text { Disagree }\end{array}$ & (3) Neutral & $\begin{array}{c}\text { (4) \& (5) } \\
\text { Strongly } \\
\text { agree / Agree }\end{array}$ & $\begin{array}{l}\text { Difference } \\
\text { (4) \& (5) - } \\
\text { (1) \& (2) }\end{array}$ & Total \\
\hline (A) I put money away in advance to be able to pay my bills & 13 & 5 & 85 & 72 & 103 \\
\hline (B) I always repay my bills in time & 8 & 8 & 87 & 79 & 103 \\
\hline (C) I take notes on my daily income & 61 & 5 & 37 & -24 & 103 \\
\hline (D) I take notes on my daily expenses & 60 & 4 & 39 & -21 & 103 \\
\hline (E) I know exactly how much money I owe & 5 & 7 & 91 & 86 & 103 \\
\hline (F) I have limit for my daily/monthly expenses & 31 & 11 & 61 & 30 & 103 \\
\hline
\end{tabular}

As shown in Table 3, the majority of the respondents (54.4\%) were able to answer the simple interest question correctly. However, the number of respondents who could not answer this particular question was nearly as high as the 'correct' respondents at is $45.6 \%$.

The next question on the division problem has the highest share of correct answers and the lowest share of incorrect answers among all the problems. $78 \%$ of the participants could answer it correctly and only $24 \%$ of them answered it incorrectly. This finding indicates that low-income households in Depok are better at simple division problems compared to other numerical problems. The third question that required a percentage calculation was answered correctly by $64 \%$ of the participants. This number is significantly different to the number of incorrect answers, in which only $36 \%$ of the sample could not get it right. The last question of the series, which required computation on a compound interest problem, shows a poor result. Out of 103 respondents, only 2 of them could answer the problem correctly. This number shows that only $2 \%$ of the participants knew how to calculate compound interest. Meanwhile, the majority of the participants (98\%) could not solve this particular problem. The compound interest problem has the highest share of the incorrect answers and the lowest share of correct answers among all the problems.

Of all the answers gathered from the participants, only 2 people out of 103 could answer all the problems correctly $(1.9 \%)$. The majority of the respondents $(39.8 \%)$ could only answer 2 questions correctly and $31.1 \%$ of the sample could answer up to three questions correctly. Meanwhile, $16.5 \%$ of the participants could only answer one problem correctly and more than $10 \%$ of them could not answer any problems correctly at all. 
Table 6. Regressions explaining financial outcomes

\begin{tabular}{lcccccc}
\hline \multirow{2}{*}{ Variables } & \multicolumn{5}{c}{ Dependent variable } \\
\cline { 2 - 7 } & \multicolumn{2}{c}{ Debt to Income Ratio } & Number of different lenders & \multicolumn{2}{c}{ Net worth } \\
\cline { 2 - 7 } Female & Sig & B & Sig & B & Sig & B \\
\hline Age & 0.528 & 12.206 & 0.129 & -0.287 & 0.617 & 30838741.28 \\
\hline Has partner & 0.514 & 5.422 & 0.534 & -0.050 & 0.872 & 4261224.529 \\
\hline Employment status & 0.056 & -13.779 & 0.498 & 0.047 & $0.002^{* *}$ & 74064647.08 \\
\hline Household size & 0.699 & -7.051 & 0.601 & 0.093 & 0.643 & -27007046.8 \\
\hline House owner & $0.028^{* *}$ & -10.357 & 0.730 & -0.016 & 0.678 & 6172866.512 \\
\hline Income & 0.932 & 1.017 & 0.798 & -0.030 & $0.00^{* *}$ & 292703313.2 \\
\hline Education & $0.009^{* *}$ & -7.878 & 0.814 & -6.769 & 0.470 & -68.281 \\
\hline Numeracy & 0.936 & -0.278 & 0.918 & -0.065 & 0.104 & 18220720.43 \\
\hline Money management & 0.220 & -6.671 & 0.218 & 0.195 & 0.677 & 7219456.054 \\
\hline Constant & 0.571 & -5.736 & $0.050^{*}$ & 0.146 & 0.958 & -1712050.415 \\
\hline Observations & 0.001 & 164.720 & 0.008 & 0.309 & 0.125 & -226208977 \\
\hline R2 & \multicolumn{7}{c}{103} & & 103 & & 103 \\
\hline
\end{tabular}

Source: Survey Data

$* \mathrm{p}=0.05, * * \mathrm{p}<0.05$

The money management skills of the sample are measured by the extent of their agreement with each statement related to financial management. As shown in Table 5, respondents generally tend to agree or strongly agree with these statements, indicating a positive behavior. Most of the sample tends to anticipate bills (A) and pay them on time (B). However, financial monitoring appears to be a weakness in that most of the participants do not take notes on daily income $(\mathrm{C})$ and daily expenses (D). Despite this, they still pay attention to their financial situation by setting a limit on their daily or monthly expenses (F) and knowing exactly how much they owe (E).

The weak financial monitoring may explain why the participants find it hard to manage expenses and make savings. As the average weekly expenses and average weekly income seem to differ very little, this condition might result from the low desire to monitor cash flow and the impulsive consumption behavior among the participants. Many respondents stated that they had to fulfill daily needs such as clothes-shopping, cigarette purchase, and household needs. This behavior implies that the participants do not take consideration of priority needs when it comes to spending meney. This way expenses can rise higher than they expected and lead to the inability to create savings.

Despite the major agreement by respondents on having a limit for daily or weekly expenses, it seems like they do not really implement this behavior in real life. The amount of money spent and money gained seem to be very similar and respondents often describe that sometimes their spending might exceed their income. Another explanation might be that they do have a limit for daily or weekly expenses but they do not establish an exact amount so that the limit on expenses is solely based on their own estimation. Even if they do have an accurate limit for expenses, participants might not be disciplined enough in observing their own limits on weekly expenses.

The influence of numeracy and money management skills are described in Table 6. In this regression, the control variables used are individual demographics and household socioeconomic 
variables. The numeracy variable is the total number of correct responses to simple interest, division, percentage, and compound interest questions. The money management variable is the average response across the six money management skills.

From the first regression, it can be seen that neither numeracy nor money management skills significantly affect the debt-to-income ratio. However, there are several significant influences found from the control variables to the debt-to-income ratio. Respondents with greater household size have a lower debt-to-income ratio by 10.36. It is also found that higherincome would decrease the debt-to-income ratio by 7.8 .

The second regression shows that money management skills are found to have a significant impact on the number of lenders. It can be seen that the money management skills affect the number of lenders positively. As these particular skills increase, the number of lenders also increases. This result is quite unexpected because it shows an opposite relationship from that usually found in previous studies on money management skills and number of lenders. Previous studies suggest that an increase in money management skills is supposed to decrease the number of lenders (French \& McKillop, 2011; Lusardi \& Tufano, 2008). This behavior is perhaps related to the systematic tendency of individuals to overestimate their financial knowledge and take on excessive levels of debt (Lusardi, 2011; Van Rooij et al., 2011). Numeracy, however, is found to have no effect upon the number of lenders.

The last regression explains the relationship between numerical and money management skills and net worth. The result shows that neither numeracy nor money management significantly influences net worth. However, the last regression model on net worth analysis shows that marital status and house ownership are found to have significant influence upon net worth. Participants who are married and live together with their partner have a tendency to own a higher value of assets. House owners will also have higher net worth.

This leads to a conclusion that financial literacy does not actually influence financial outcomes among low-income households in Depok. There are no control variables that significantly affect the number of lenders.

The results of this research have some similarities to those of the study conducted by Cole, Sampson, \& Zia (2011), who performed a survey on financial literacy and demand for financial products in Indonesia. They found that financial education programs had a modest effect in increasing demand for financial products, particularly demand for bank accounts. In this research, we examine the effect of financial literacy on financial products in terms of the usage of consumer debt. We find that financial literacy in terms of money management skill only affects one aspect of the usage of debt, namely the number of lenders. Both our study and the research conducted by Cole, Sampson, \& Zia (2011) find that financial literacy only has a relatively small effect on demand for financial products.

\section{Conclusion}

This study examines the relationship between financial literacy and number of lenders in lowincome households in Depok, West Java, Indonesia. The financial literacy variable in this research uses two core competence components, namely numerical and money management skills, as a measurement to define the financial literacy level among low-income households 
in Depok. It is found that numeracy skills do not significantly affect the number of lenders. However, money management skills do.

Numerical skills are closely related to the mathematical problems that may sometimes create confusion among low-income households. Respondents often explained that they find it hard to understand the concepts of interest and percentage when they face a related situational problem, especially when it comes to the process of getting a loan from formal institutions. They would rather see a real nominal value on paper explaining how much they should pay over a certain period. Despite the respondents' statement, over-indebtedness among low-income households in Depok does not depend on the ability of the individuals to calculate mathematical problems. Thus, numeracy skills play no role in determining the number of lenders used by the debtors.

Money management skills are found to significantly influence the number of lenders significantly. Moreover, these particular skills affect the number of lenders positively. This result is surprising because previous studies suggest that the number of lenders would tend to decrease as money management skills improve. The reason for this positive correlation to the number of lenders is perhaps related to the systematic tendency of individuals to overestimate their financial knowledge and take on excessive levels of debt (Lusardi, 2011; Van Rooij et al., 2011).

The over-indebtedness state among low-income households should be a concern for the local government in Depok. Many households have monthly expenses greater than their financial capabilities and therefore accumulate debt over time. It is important to improve the level of financial knowledge by enhancing numeracy and money management skills that could help individuals make better financial decisions in the future. The study suggests that financial literacy programs can be effective when it is targeted towards a specific audience and area of financial activity as opposed to being a one-size-fits-all financial education program (Lusardi \& Mitchell, 2014; Martin, 2004).

\section{References}

Cole, S., Sampson, T., \& Zia, B. (2011). Price or Knowledge? What Drives Demand for Financial Services in Emerging Markets? Journal of Finance LXVI (6), 1933-1967.

D. French, \& D. McKillop. (2016). Financial Literacy and Over-Indebtedness in Low-Income Households. International Review of Financial Analysis 48, 1-11. doi: 10.1016/j. rfa.2016.08.004

D’Alessio,G., \& Lezzi, S. (2013). Household Over-Indebtedness; Definition and Measurement with Italian Data. Retreived from http://www.bis.org/ifc/events/6ifcconf/dalessioiezzi.pdf

Disney, R., Bridges, S., \& Gathergood, J. (2008). Drivers of Over-Indebtedness. Centre for Policy Evaluation.

Garðarsdóttir, R. B., \& Dittmar, H. (2012). The relationship of materialism to debt and financial well-being: The case of Iceland's perceived prosperity. Journal of Economic Psychology, 33(3), 471-481. 
Gathergood, J. (2012). Self-control, financial literacy and consumer over-indebtedness. Journal of Economic Psychology, 33(3), 590-602.

Hung, et al. (2009). Defining and measuring financial literacy. RAND Labor and Population WR-708.

Lea, S., Webley, P., \& Walker, C. (1995). Psychological factors in consumer debt: Money management, economic socialization, and credit use. Journal of Economic Psychology, $16(4), 681-701$.

Lusardi,A., \& Mitchell, O. S. (2011a). Financial literacyandplanning: Implications for retirement well being. In O. S.Mitchell, \& A. Lusardi (Eds.), Financial literacy: Implications for retirement security and the financial marketplace. Oxford: Oxford University Press.

Lusardi, A., \& Tufano, P. (2009a). Debt literacy, financial experiences, and overindebtedness. NBER Working Paper 14808.

OECD INFE (2011). Measuring financial literacy: Core questionnaire in measuring financial literacy: Questionnaire and guidance notes for conducting an internationally comparable survey of financial literacy. Paris: Organization for Economic Co-Operation and Development.

OJK (2013). Financial Literacy in Indonesia and National Strategy. Retrieved from http:// www.ojk.go.id.

Perkumpulan Akses Keuangan Indonesia. (2016). Indonesia Over-Indebtedness Study: "Why Microfinance Clients Take Multiple Loans". Retreived from www.microsave.net/files/ pdf/Over_indebtedness_Study_Indonesia_2016.pdf

Potrich, et al. (2016). Development of a financial literacy model for university students. Management Research Review, Vol. 39 Iss 3 pp. 356 - 376.

Rijas, Anu. (2011). Money management in blended and nuclear families. Journal of Economic Psychology 32, 556-563. doi: 10.1016/j.joep.2011.02.006

Van Rooij,M., Lusardi, A., \& Alessie, R. (2012). Financial literacy, retirement planning, and households wealth. Economic Journal, 122, 449-478.

Van Rooij,M., Lusardi,A., \&Alessie, R. (2012). Financial literacyand stock marketparticipation. Journal of Financial Economics, 101, 449-472. doi: 10.1016/j.jfineco.2011.03.006 